\title{
Notes on philosophy of technology: the technological condition: an anthology
}

Quote: RAMA, Jander Luiz. Notes on philosophy of technology: the technological condition: an anthology. Porto Arte: Revista de Artes Visuais. Porto Alegre: PPGAV-UFRGS, v. 23, n. 38, p.243-245, jan.-jun. 2018. ISSN 0103-7269 | e-ISSN 2179-8001. DOI: http://dx.doi.org/10.22456/2179-8001.80808

\section{Translated by Roberto Cataldo Costa}

Abstract: Notes on Philosophy of Technology: The Technological Condition - An Anthology, a collection of academic articles dedicated to philosophy of technology, edited by Robert C. Scharff and Val Dusek.

\section{Keywords: Technology. Philosophy. Contemporary art.}

Science and technology, as a subject and a medium, are present in several works of art and reflect the very human condition in face of increasingly fast changes brought about by technological advances, especially in recent decades. Works by artists such as Stelarc, Nam June Paik, Eduardo Kac or Chris Burden relate several issues present in high technology with their complex and difficult implications for human affairs and nature.

For instance, Stelarc's performances and prostheses seek inventive ways to integrate the technological foreign body into the human body itself. Similarly, Paik builds technological paraphernalia such as artificial bodies and robots, in search of other meanings for images in his videos. Dealing with intelligent propositions based on mechanisms of a fictitious city, Metropolis II, or with a transgenic rabbit, GFP Bunny, Burden and Kac establish a conversation with problems that touch humankind's major fears such as the hallucinating pace of machines applied to urban fabric and genetic engineering applied to food and pharmaceutical products.

As striking as the speed of techno-scientific advances, these works challenge us to seek more elaborate reflections on various levels about this indisputable presence. The implications of advanced technology are not neutral in society at large, nor are they apolitical, let alone uncritical. The debates that have emerged from the outset, in which man uses technology to overcome the physical limits of his nature, reach a new level today.

Technology experts and leaders in robotics laboratories have been recently concerned about the harmful applications of Artificial Intelligence (AI) in warfare mechanisms and armed combat strategies. In 2017, a group of renowned technicians and experts wrote a letter urging the UN to include AI applied in combat in the banned weapons list (CCW). According to them, if such technological tool is applied to war, part of humanity is at risk as a result of machine efficiency in the hands of dictators, terrorists or even hackers.

Based on issues pertaining to art or everyday life, advanced technology and its implications can be best discussed within philosophy of technology. While the $20^{\text {th }}$ saw several debates driven by ethical issues involving technological development and its application in war and society, these issues gain a different dynamic in this third millennium, involving new phenomena in philosophical debates related to the beneficial/complex place of technique in human relations and affairs. Food production, social media networks, robotics and automation, genetic engineering, among others, generate innumerable reflections and cannot be treated only as practical knowledge. Even though some stances are so opposed that they may lead to technophobia or technophilia, the debate on nuances of technological applications and their effects on different areas of human development is necessary. According to Walter Brugger:

In this respect, while the beneficial power of technology becomes apparent - without which it would not have been possible for mankind and its culture to reach the present stage of development - one cannot ignore a series of undesirable consequences that clearly do not emerge entirely from the essence of technique, but often from its defective place into the global domain of life. ${ }^{1}$

The book edited by Robert C. Scharff and Val Dusek in 2003 and re-published in 2014 ( $2^{\text {nd }}$ edition), entitled Philosophy of Technology: The Technological Condition: an Anthology covers exhaustive material on the main strands of philosophy of technology.

Scharff and Dusek's anthology is divided into six distinct parts: Part I - The Historical Background, Part II - Philosophy, Modern Science, and Technology, Part III - Defining Technology, Part IV - Heidegger on Technology, Part V Technology and Human Ends e Part VI - Technology as Social Practice. This division is most welcome because it

1. BRUGGER, 1962, p.400. 
organizes classical philosophers and their approaches on the subject and the development of more specific issues by current thinkers.

The first edition of that compilation, published in 2003, grew from the needs and experiences of editors as philosophy of technology professors. The second edition takes into account new approaches to this relatively new field of philosophy. While the number of such anthologies has grown, the one in question is very relevant in approaching key issues of philosophy of technology.

According to the authors, Part I was intended to provide a compilation of some familiar discourses in Western philosophical tradition whose views on the relationship between knowledge and its applications have played an important role in creating an inherited context where contemporary philosophy of technology is relevant. The selection was designed to encourage the analysis of why philosophy of technology is relatively recent in its origin in comparison to other philosophical topics.

Part II includes contemporary readings that emphasize and critically evaluate the basic assumptions that have been passed on to us since the $19^{\text {th }}$ century: science; the relationship between modern science and technology; and the proper treatment of philosophy in both. It also addresses a brief history of the rise and fall of logical positivism, or the Vienna Circle, of philosophy of science, along with the emergence of several post-positivist and alternative critiques.

Texts in Part III underscore issues related to the attempt to define technology, as well as how those definitions remain unstable and pluralistic. Many of the recent efforts to define technology still tend - voluntarily or not - to stances on two controversial topics, namely: whether and how modern science has transformed pre-scientific technologies; and whether technology is essentially applied science.

The essay in Part IV addresses Martin Heidegger's impressions in The Question Concerning Technology and a sample of responses to it. Heidegger's essay presents what is probably the most influential- although not the most popular - stance in the field.

The views in Part $V$ raise a set of general points about the proper role of technology in mediating our relationships with the natural world. One section considers whether human beings are essentially users of tools and, therefore, susceptible to technological problems only when they are involved in technological activity. The second section questions whether the influence of technology in our lives can be strong and pervasive enough to operate as an autonomous force and makes the whole optimistic "control" discourse seem naïve - as some writers have argued. The essays in the third section establish relationships between human nature and technological power, addressing the ecological issue. They also debate the legitimacy of the famous Baconian imperative that encourages us to think of "knowledge" primarily as that which gives us the power to control our natural environment.

Part VI focuses on issues that arise when technology is seen not so much as an expression of human nature or as an instrument for controlling nature but as a specific and increasingly dominant definition of sociocultural practices. The essays in the first section address technology's mediation in most of our relationships, not only with nature but also among ourselves. In Technology and Cyberspace, in the second section, several authors consider the intriguing question of whether the cyber revolution promises to alter the basic notions of who we are, what the mind or consciousness are, and what the experience of reality is. The third section focuses on an issue implicit in many other readings, namely, the implications of technollogy for the future of politics and democracy in our social practice and its increasingly technological forms.

The chapter on Heidegger's work (Part IV - Heidegger on Technology) is highly interesting for articulating more specifically The Question Concerning Technology, from the 1950s, with four other current texts. Confronting the main ideas of Heidegger, Comte and Borgmann, the chapter's authors such as Scharff and Feenberg raise important elements for the debate on advanced technology in our society.

Finally, several texts included in these six parts present distinct philosophical stances on technology, with abundant material that can nourish arguments on several issues and involving technology in the present time. They also refresh debates about contemporary artistic productions that also deal with technology as a medium and and a subject. 


\section{REFERENCES}

BBC Brasil. Líderes em tecnologia pedem proibição de 'robôs assassinos'. Available at: <http://www.bbc.com/portuguese/ geral-40997536>. Accessed on August 21, 2017.

BRUGGER, Walter. Dicionário de filosofia. São Paulo: Herder, 1962.

SCHARFF, Robert C.; DUSEK, Val. Philosophy of Technology: The Technological Condition: an Anthology. $2^{\text {nd }}$ ed. Oxford: Blackwell, 2014.

Jander Luiz Rama: is a visual artist and a PhD student in Visual Poetics at PPGAV-UFRGS and holds a Master's Degree in Visual Poetics from the same institution. He has published articles, participated in project selections for state funding, held numerous exhibitions, and received awards such as the Iberê Camargo Scholarship - Ateliê de Gravura (2013), the IEAVI Award (2014), the Açorianos Award for Printmaking (2014), and the Incentive to Creativity Award of the $21^{\text {st }}$ CMPA Salon (2016). He is a member of the research group Expressions of the Multiple CNPq-UFRGS..

(*)This text was submitted in September 2017. 